\title{
Deconstructing the myth of Pasewalk: Why Adolf Hitler's psychiatric treatment at the end of World War I bears no relevance
}

\author{
Jan Armbruster ${ }^{1}$, Peter Theiss-Abendroth ${ }^{2}$ \\ 1 Klinik für Forensische Psychiatrie und Psychotherapie, Helios Hanseklinikum Stralsund, Stralsund, Germany. \\ 2 Touro College Berlin, Berlin, Germany.
}

Received: 9/15/2015 - Accepted: 6/11/2016

DOI: $10.1590 / 0101-60830000000085$

\begin{abstract}
Background: Even more than 70 years after the end of WW II, questions regarding the personality of dictator Adolf Hitler (1889-1945) remain unresolved. Among them, there is a focus on the problem of his state of mental health, in particular on the possible relevance of the medical treatment he received for a war injury at the military hospital of the small German town of Pasewalk in the last days of WW I. Some authors have come to postulate a profound change of his personality due either to a psychic trauma suffered or a hypnotic therapy he supposedly underwent for curing a hysterical blindness. Objectives: The assumptions about Hitler's war injury which rely on only two significant sources shall be assessed for their validity. Methods: Existing historical sources and inferred hypotheses will be discussed in the light of alternative interpretations. Results: The mentioned suppositions reveal their highly arbitrary character: neither a hysterical blindness of Hitler's nor a hypnotic treatment at Pasewalk military hospital can be substantiated. Discussion: Given the fact that Hitler's medical sheet is most likely irrevocably lost, the authors plea for the acceptance of the limitations of historical research, even more so since the occurrences in Pasewalk lack any deeper importance for a historic assessment of Hitler's personality.
\end{abstract}

Armbruster J, Theiss-Abendroth P / Arch Clin Psychiatry. 2016;43(3):56-9

Keywords: Adolf Hitler, Edmund Forster, Ernst Weiß, Pasewalk, hysterical blindness.

\section{Introduction}

Though more than 70 years have passed since the end of World War II, that outburst of extreme violence in Central Europe remains somewhat enigmatic: how could a country like Germany, which considered itself among the world's most civilized nations, become the perpetrator of such extreme destructiveness? One of the explanations easily at hand points to the person of Adolf Hitler (1889-1945) and his charismatic, even hypnotic aura. But then again, another problem arises: how could such a mediocre figure, a failed landscapist, turn into such a powerful and highly influential creature?

Here is where some authors make the assumption that psychiatry plays a role, stating that Hitler underwent a profound personality alteration at the end of World War I, when he fought with the rank of lance corporal in a Bavarian infantry division. They postulate that the presumed change was the result of either a severe psychic trauma suffered when his unit was attacked with mustard gas in the trenches close to the Belgian town of Ypern in October 1918, or from the psychiatric treatment he supposedly received afterwards in the Northern German town of Pasewalk, where he was a patient at the local military hospital from October 21 to November 19 of that year. The incident on the Western front, Hitler's temporary blindness, and his medical treatment in the Pomeranian town can be considered proven facts. However, the speculations that rise from them cannot claim any reliable evidence in their favour. Yet they spread rapidly, even finding their way into Brazilian and Portuguese scientific literature ${ }^{1-6}$ and thus creating what the authors of this paper have come to call the "myth of Pasewalk". This study aims to acquaint the reader with the main arguments brought forth by the advocates of this delineated narrative, to scrutinize their reliability and, finally, to reveal their highly speculative and implausible nature. And, while it cannot prove the opposite, this study makes a strong plea for the intellectual honesty of accepting the limitations of historical research.

\section{State of the discussion in general}

A vast number of studies dealing with questions of Hitler's overall health have been published in English and German. Some of them come from his followers or ex-doctors and must be read with due caution $^{7-9}$, but there are also more recent studies ${ }^{10-12}$.

When focusing on Hitler's mental health, we find some remarkable statements already made by renowned German psychiatrists of the time. University professor Oswald Bumke (1877-1950), teaching in cities such as Rostock, Leipzig, Munich and then German Wrocław, claimed to have hinted strongly at Hitler when lecturing on prestige-craving ("geltungsbedürftig") hysterical personalities and schizoid, autistic fanatics, as the terminology of the time called it ${ }^{13}$. The best-known statement from the time comes from Karl Willmanns (1873-1945). He is said to have explained Hitler's 1918 blindness as a hysterical reaction in a 1933 lecture ${ }^{14-16}$. Supposedly because of this, he lost his position as a full professor at Heidelberg University. A similar story has been told about Hans Gruhle (1880-1958). Even up to the present, psychiatrists maintain the hypothetical diagnosis of a hysteria ${ }^{17}$.

Literature provides an even wider spectrum of mental disorders Hitler may have suffered from, ranging from a paranoid personality accentuation with ideas of persecution and grandeur over a narcissistic and hysterical psychopathy including hysterical blindness or paresis respectively, or, alternatively, a schizoidia up to a paranoid schizophrenia with hallucinations of cadaveric poison, coenesthesias, bacillophobia and delusions of persecution and blessedness. The pathographic compilation "Genie, Irrsinn und Ruhm" ("Genius, insanity, and glory") provides a comprehensive survey of these psychiatric hypotheses, as well as of a number of physical diseases like Parkinson's, encephalitis and a syphilis with ocular symptoms ${ }^{18}$; see also the recent overview ${ }^{19}$. However, all of these vast allegations lack any objective basis in terms of reliable historical documents.

\section{Hitler in Pasewalk}

In recent years, the debate has concentrated on a brief episode in late 1918, when the young Adolf Hitler, a low-ranking soldier in the German army at the time, received medical treatment at the military reserve hospital in the Pomeranian town of Pasewalk, about $150 \mathrm{~km}$ north of Berlin. In 1976, the American historian Rudoph Binion made 
the assumption that the German psychiatrist Edmund Robert Forster (1878-1933), then chief surgeon in service of the German imperial navy, but in civil life first senior doctor at the Berlin University Hospital Charité, and from 1925 onwards professor at Greifswald University Hospital, had been in charge of Hitler's treatment and that this and the fear of reprisal was the reason for Forster's subsequent suicide $^{20}$. By applying a so-called psycho-historical approach, developed by Lloyd deMause in the 1970s, Binion postulated that, in the last days of WW I, Hitler turned into a charismatic leader personality and a fervent anti-Semite, demonstrating characteristics he never had before. Binion holds Edmund Forster's supposed "miraculous cure" responsible for this alteration.

This study focuses on the validity of this hypothesis, which relies almost exclusively on two very special documentary sources, given that Hitler's medical charts are still missing. The first is a US Navy intelligence report from March 1943, reporting a testimony given in Reykjavik by the Jewish refugee Karl Kroner (1878-1954), who had worked as a neuropsychiatrist in Berlin and claimed to have been present at Hitler's medical examination. The report, entitled "ADOLF HITLER'S BLINDNESS (A psychological study)"21 draws a connection between Hitler, Forster (though incorrectly referring to him as "Förster") and the diagnosis of hysteria. Additionally, Kroner accused Hitler not only of murdering Edmund Forster because of what he knew about his former patient, but also of killing his own niece, Geli Raubal, for refusing to submit to her uncle's sexual perversions. Furthermore, Kroner denounced Hitler as a coward in war, undeserving of his military decorations. Unfortunately, Kroner died too soon for historians to interview him about his allegations after the war, but the British neuropsychologist David Lewis had the opportunity to talk to his son, who provided some insight into his father's situation at the time he delivered this testimony. Having barely escaped a German concentration camp, Karl Kroner found it difficult to make a living in Iceland because his medical diploma wasn't recognized by the local authorities22 (pp279-81; in Portuguese: 3 p282). Thus, he may have tried to accelerate his visa process to the US by making himself irreplaceable. Given the obvious exaggerations and distortions in his narrative and the tremendous pressure he was under, he may serve as a witness for a number of things - but certainly not for such a crucial aspect of history as the one in question here. After all, Kroner did nothing but repeat rumors that were circulating in the academic world at that time ${ }^{14}$ (p75). This leads to the second, and even less "documentary" piece of evidence Binion and subsequently various other present: a novel, written by the desperate emigrant author Ernst Weiß (1882-1940). Given that all of Binion's successors ${ }^{1-6,22-26}$ emphasize its significance, the novel shall be closely examined below.

\section{Fact or fiction - Fiction for fact}

Weiß came from a unique cultural context that, like so many others in Europe, has ceased to exist: the ambience of German-speaking Jewish intellectuals and artists in an area that now belongs to the Czech Republic. A relatively well-known author in his time, writing predominantly in the sober style of New Realism (Neue Sachlichkeit), which became popular in German language literature after the loss of World War I, he was friends with Franz Kafka (1883-1924), with whom he shared this specific background ${ }^{27}$. Born in Brno, Moravia, Weiß began studying medicine in Prague and then moved to Vienna, where he may have attended Sigmund Freud's lectures $\left.{ }^{28} \mathrm{p} 15,{ }^{29} \mathrm{p} 136,{ }^{30} \mathrm{p} 143,{ }^{31} \mathrm{p} 186,{ }^{32} \mathrm{p} 10,{ }^{33} \mathrm{p} 18\right)$. He specialized in surgery, working with some of the era's leading authorities, such as Theodor Koch (1841-1917) in Bern, the first surgeon to win the Nobel Prize. Although his interest in literature eventually got the upper hand and led him to give up his medical work in 1920, his entire oeuvre shows his profound concern with the psychological and ethical intricacies of his original profession ${ }^{33,34}$, and mental health issues in particular ${ }^{35}$. He fled from the Nazis when Hitler seized power and settled under miserable circumstances in Paris, where he committed suicide the day German troops invaded the city in 1940. His last novel The Eyewitness (German original: Der Augenzeuge, in Portuguese A Testemunha Ocular), written in 1938 under tremendous pressure, had fallen into oblivion until it was published posthumously, 25 years later ${ }^{36}$, and was subsequently translated into English, Spanish and French. Like many of his other novels, it consists of a fictitious (auto) biography of a physician, in this case a psychiatrist. Similar to Weiß's experience, the protagonist and narrator serves in the war as a physician ${ }^{37}$ (pp11,107-8). By the end of the war, he is assigned the duty of providing special care for the mentally afflicted in the psychiatric department of Pasewalk military hospital, where, among his patients, he encounters a sleepless, rambling, unappealing antiSemite called A. H., ill with mild conjunctivitis and a psychogenic blindness. Since the young doctor himself had suffered long-lasting humiliation both in his private and professional life, he sees his chance to excel, and attempts to cure his patient by applying a strong suggestion to him: possibly being as extraordinary a man as Jesus or Mohammed, A.H. might be able to overcome his ailment through pure willpower - in order to fulfil his destiny as a savior of defeated Germany $^{36}$ (p118). The cure turns out to be a success, and events take their well-known course.

The novel has been frequently misinterpreted with claims of it being of documentary value and representing real occurrences in that specific period of Hitler's life. Yet there is no historical evidence whatsoever that Weiß had privileged access to Hitler's lost medical files or any other source of in-depth information ${ }^{38}$ (p224). Quite the contrary: a careful reading of The Eyewitness reveals the various efforts Weiß took with the aim of making it very clear that he was by no means to be confused with the fictitious narrator of the story ${ }^{37}$ (p113). A good look at his other novels emphasizes the literary nature of the book, as many of them deal with questions of power and helplessness in medical affairs ${ }^{39}$ (pp36-7). The assumption that Weiß's novel provides something like a docu-fiction for potentially crucial days in Hitler's life can neither be proven nor refuted ${ }^{33}(\mathrm{p} 99,6)$. It simply needs to be taken as purely hypothetical.

\section{Critical voices}

In the light of the insufficiency of the provided sources, we advocate being extremely careful about a possible mental disorder on Hitler's record ${ }^{39,40}$. No one has been able to come forth with reliable historical material for the allegations made, whether on the making of Ernst Weiß's novel or on Edmund Forster's biography. We also cannot be sure that Forster was present at Pasewalk at all during Hitler's treatment, nor do we know of any positive proof that his involvement with Hitler could be considered a motivation for his suicide. Quite the contrary: documentary sources at Greifswald University provide strong evidence that Forster fell victim to a personally motivated attack by a former member of staff and subsequently was dismissed by Nazi authorities - a chain of events that caused the ambitious scientist to fall into a deep depression and take his own life ${ }^{41}$. Another open question continues to be how Forster is supposed to have transferred information on Hitler and his medical sheet to Ernst Weiß in Paris ${ }^{39,40}$. The aforementioned arguments that construe a link between Hitler's hypothesized treatment in Pasewalk and Edmund Forster's death are based on vague evidence, the sources for which can most likely be traced back to Forster himself. These aspects have been prudently challenged before by Maranhão-Filho and da Rocha e Silva ${ }^{6}$.

After all, the evidence provided by Forster's relatives as insinuated by Lewis can hardly be considered convincing: the only thing the son Balduin, a thirteen-year-old boy at the time of his father's suicide, remembers for sure is his mother's statement saying that Forster had assessed Hitler and called him a hysteric ${ }^{42}$. Yet the context of this assessment and whether it involved some kind of therapy remain unknown.

Hitler's medical sheet, the only potentially conclusive document, no longer exists. The above-mentioned US intelligence dossier from 1943, discovered in the 1970s by Hitler's North American biographer 

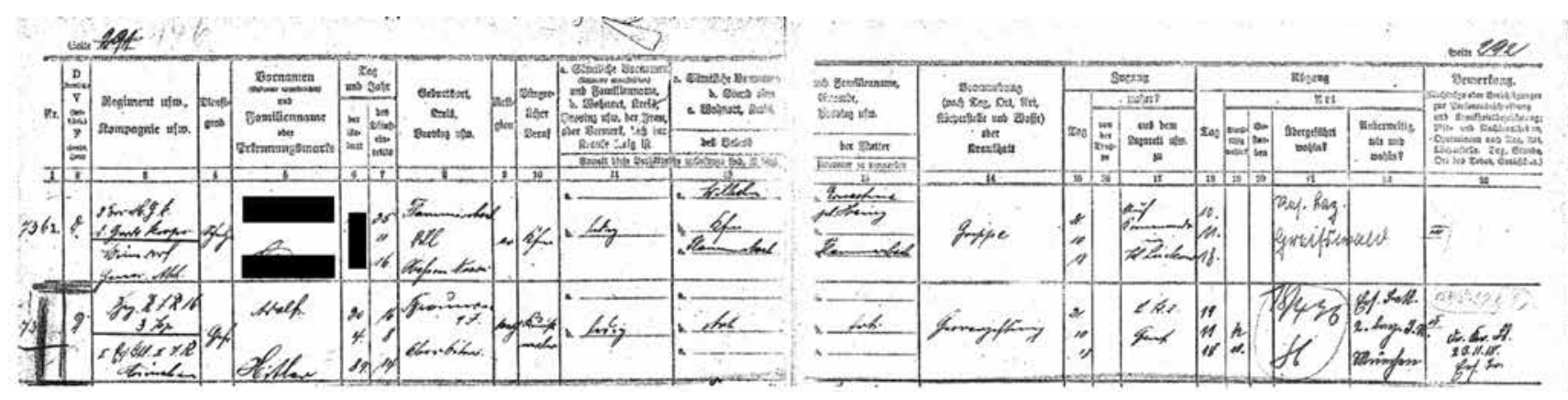

Figure 1. Excerpt of the medical book (Hauptkrankenbuch) of Pasewalk (Source: Krankenbuchlager Berlin, Sammelurkunde Nr. 28103, HKB Res.-Laz. Pasewalk, p291); see row 2 for the only source available on Hitler's 1918 medical treatment: e.g. col 5 for his name, col 9 for his denomination (catholic), col 11 for his marital status (ledig = unmarried), col 14 for the diagnosis (Gasvergiftung = gas poisoning; compare informations for the blackened patient in the row above: Grippe = influenza which indicates that Hitler was not being treated in a specialized department), col 15 for date of entry, col 18 for date of dismissal.

John Toland ${ }^{43}$ in the National Archives in Washington, at first seemed to shed light on Hitler's stay at Pasewalk. But as Katz remarked critically shortly afterwards, Kroner did not go beyond "reproducing" well-known opinions (of Forster's) - German psychiatrists were already discussing hysteria as a possible diagnosis of the selfproclaimed dictator at that time ${ }^{14}$. Based almost exclusively on this intelligence report as the only historical source, later authors such as Post (1998), Lewis (2003), Horstmann (2004), and Köpf (2005)22-24,26 created a myth, the development and continuation of which have been investigated previously ${ }^{40}$.

Since the relevant sources are missing a factual consideration of Hitler's stay at Pasewalk military hospital, we are inevitably led to the conclusion that the issue of his alleged hysterical blindness simply cannot be resolved. Nor can the recent contributions made by historians Thomas Weber ${ }^{44}$ and Henrik Eberle ${ }^{45}$ change anything regarding the issue. Calling upon Lewis, Köpf and Horstmann, Weber presented a new narrative by introducing the German neurologist Otfrid Foerster (1873-1941) as another colporteur of a mental disorder as yet unmentioned in academic discourse, but who was supposed to have had knowledge of Hitler's medical file ${ }^{44}$ (p295). However, shortly afterward, Eberle proved him wrong by pointing out the administrative pathways of Pasewalk's files and presenting for the first time an excerpt of a so-called medical book used there in 1918 for a comprehensive documentation of all patients in the ward ${ }^{45}$ (pp44-7). It is stored in the central archives of Berlin-Buch and indeed represents a quite specific document of the medical treatment performed in Pasewalk military hospital. For lance corporal Adolf Hitler, it definitively and exclusively shows the diagnosis of gas poisoning (Gasvergiftung) (Figure 1). This diagnosis is identical with what other documents from the Federal Archives Berlin reveal, which have been published by David Lewis in this journal ${ }^{3}$ (Figure 1) some years ago.

This, of course, raises the question as to why anyone would register Hitler, a totally unknown, low-rank soldier at the time, under a false diagnosis. Supporters of the "hysteria hypothesis" still owe us an explanation for this. Eberle, on the other hand, emphasized that, contrary to their repeated claims, Pasewalk was by no means a specialized institution for psychiatric patients and that "gas poisoning" is one of the more frequent diagnoses to be found in the medical book, whereas some other patients were categorized as "nervenkrank" (literally "of ill nerves", a common expression at the time for the mentally disordered $)^{45}$ (p46).

\section{Conclusion}

The reticence as shown by the majority of historians concerning Hitler's stay at Pasewalk military hospital continues to be more than appropriate. After all, with the medical sheet missing, there is no way of substantiating that he was ever treated by Edmund
Forster. Moreover, even if it were true, it wouldn't signify more than a marginal episode in Hitler's biography for a historical assessment of his person. Instead of adding to our knowledge by presenting new sources, recent contributions have publicized a myth that seems problematic in two ways: on one hand, it reduces Edmund Forster to having been Hitler's therapist, which doesn't do justice to his personality and achievements. On the other hand - and this weighs more heavily - it diminishes and relativizes Hitler's responsibility for his acts. In the opinion of the historian Ian Kershaw, it minimizes the complex developments that led to the mass murder of Jews during the Second World War to the alleged trauma of one single person in $1918^{46}$ (p101). And, last but not least, this indirectly follows the logic of Hitler's "Mein Kampf", where he describes the shift his life allegedly took during his hospital stay, including his decision to become a politician ${ }^{47}$ (pp221,225). This implicates the risk of continuing the Myth of Hitler (the so-called "Führer-Mythos"). In conclusion, it remains to be said that Hugh Redwald Trevor-Roper's ${ }^{\star}$ 1947 statement remains valid: "Whatever Hitler's psychological condition may have been, [...] on such a subject, and in so unique a character, it would be imprudent to speculate" 48 (p53).

\section{Declaration of interest}

There are no conflicts of interest.

\section{References}

1. Portela Câmara F. O psiquiatra do Führer. Psychiatry on line Brasil 2001 [cited 2014 Jul 31]; 6(1). Available from: http://www.polbr.med. br/ano01/port0101.php.

2. Köpf G. A cegueira histérica de Adolf Hitler: histórico de um boletim medico. (The hysterical blindness of Adolf Hitler: record of a medical chart). Rev Psiq Clin. 2006;33(4):218-24 [abridged translation from German of Köpf 2005].

3. Lewis D. Trinta dias na casa de tiros. O estranho caso do Dr. Edmund Forster e Adolf Hitler. [Thirty days at the shooting house. The strange case of Dr. Edmund Forster and Adolf Hitler]. Rev Psiq Clin. 2006;33(5):27685

4. Haag C. O dia em que Hitler chorou. As terríveis consequências da cegueira histérica do ditador na Primeira Guerra Mundial. [The day on which Hitler cried. The terrible consequences of the dictator's hysterical blindness during the First World War]. Pesquisa Fapesp 2007 [cited

* Hugh Redwald Trevor-Roper (1914-2003), an intelligence officer in World War II for British Secret Intelligence Service Military Intelligence Section 6 (SIS MI 6) and a professional historian, was assigned the task of investigating the final days of Hitler's life and the closer circumstances of his death. In 1947 he published his results in his book "The Last Days of Hitler". 
2014 Aug 4]; 133:88-91. Available from: http://revistapesquisa.fapesp. br/2007/03/01/o-dia-em-que-hitler-chorou/.

5. Gramary A. O internamento de Adolf Hitler no Hospital de Pasewalk, um Caso de Cegueira Histérica. [The Adolf Hitler Hospitalization in Pasewalk, a Case of Hysterical Blindness?]. Saúde Mental. 2008;10(6):4750.

6. Maranhão-Filho $P$, da Rocha e Silva CE. Hitler's hysterical blindness. Facts or fiction? Arq Neuropsiquiatr. 2010;68(5):826-30.

7. Röhrs HD. Hitlers Krankheit: Tatsachen und Legenden: Medizinische und psychische Grundlagen seines Zusammenbruchs. Neckargemünd: Kurt Vowinckel; 1966.

8. Irving D. Wie krank war Hitler wirklich? Der Diktator und seine Ärzte. München: Wilhelm Heyne; 1980.

9. Schenck EG. Patient Hitler: Eine medizinische Biographie. Düsseldorf: Droste; 1989.

10. Redlich F. Hitler: Diagnosis of a Destructive Prophet. Oxford: University Press; 1998.

11. Neumayr A. Hitler. Wahnideen - Krankheiten - Perversionen. Wien: Pichler; 2001.

12. Neumann HJ, Eberle H. War Hitler krank? Ein abschließender Befund. Bergisch-Gladbach: Gustav Lübbe; 2009.

13. Bumke O. Erinnerungen und Betrachtungen. Der Weg eines deutschen Psychiaters. 2nd ed. München: Richard Pflaum; 1953. p. 174-7.

14. Katz O. Prof. Dr. med. Theo Morell: Hitlers Leibarzt. 2nd ed. Bayreuth: Hestia; 1983.

15. Lidz R, Wiedemann HR. Karl Willmanns (1873-1945): ...einige Ergänzungen und Richtigstellungen. Fortschr Neurol 1989; 57:160-1.

16. Riedesser P, Verderber A. Maschinengewehre hinter der Front: Zur Geschichte der deutschen Militärpsychiatrie. Frankfurt a. M.: Fischer; 1996.

17. Krausbeck E. Sein Lieblingswort war Ich - Wie krank war Adolf Hitler? Ein literarisch-kulturhistorisches Sachbuch zur Psychopathologie. Saarbrücken: Verlag Dr. Müller; 2011. Chapter 2, Hitler im Blick des Psychiaters; p. 33-68.

18. Lange-Eichbaum W, Kurth W. Genie, Irrsinn und Ruhm; vol. 8. Die Politiker und Feldherren. 7th ed. Completely revised by W Ritter. München, Basel: Ernst Reinhardt; 1992. Chapter 14, Adolf Hitler; p. 74-91.

19. Surhone LM, Tennoe MT, Hennessow SF (Ed.) Adolf Hitlers Psychopathographie. Psychopathologie, Psychiatrie, Pathographie, C.G. Jung, Walter Charles Langer, Erich Fromm, Fritz Redlich. Beau BassinRose Hill: Betascript; 2010. p. 1-15.

20. Binion R. Hitler among the Germans. New York: Elsevier; 1976.

21. Intelligence Report 24-43, 1943 March 21. ADOLF HITLER'S BLINDNESS (A psychological study). National Archives Washington, Military Reference Branch, Office of Naval operations Intelligence Report, Nr.31963.

22. Lewis D. The man who invented Hitler: The making of the Führer. London: Headline; 2003.

23. Post DE. The Hypnosis of Adolf Hitler. J Forensic Sci. 1998;43:1127-32.

24. Köpf G. Hitlers psychogene Erblindung: Geschichte einer Krankenakte. Nervenheilkunde. 2005; 24(9):783-90.

25. Koch-Hillebrecht M. Hitler: Ein Sohn des Krieges: Fronterlebnis und Weltkrieg. München: Herbig; 2003.

26. Horstmann B. Hitler in Pasewalk: Die Hypnose und ihre Folgen. 2nd ed. Düsseldorf: Droste; 2005
27. Engel P. Ernst Weiß und Franz Kafka: Neue Aspekte zu ihrer Beziehung. Text und Kritik. 1982;76:67-78.

28. Engel P. Ernst Weiß - eine Skizze von Leben und Werk. Text und Kritik. 1982;76:13-9.

29. Bredel W. Ein Hoffender ohne Hoffnung. In: Engel P, editor. Ernst Weiß. Frankfurt a. M.: Suhrkamp; 1982. p. 134-8.

30. Kesten H. Vorwort zu Der Augenzeuge. In: Engel P, editor. Ernst Weiß. Frankfurt a. M.: Suhrkamp; 1982. p. 141-56.

31. Lattmann D. Posthume Wiederkehr: Ernst Weiß - Arzt und Schriftsteller. In: Engel P, editor. Ernst Weiß. Frankfurt a. M.: Suhrkamp; 1982. p. 184-200.

32. Hinze K-P. Zum Leben und Werk von Ernst Weiß. In: Weiß E. Der zweite Augenzeuge und andere ausgewählte Werke. Edited and introduced by K-P Hinze. (Verschollene und Vergessene). Wiesbaden: Steiner. 1978. p. 9-18.

33. Streuter M. Das Medizinische im Werk von Ernst Weiss. Medical dissertation. Herzogenrath: Murken-Altrogge; 1990.

34. Wondrák E. Ärztliches und Arzttum im Werk von Ernst Weiß. In: Engel P, editor. Ernst Weiß. Frankfurt a. M.: Suhrkamp; 1982. p. 249-60.

35. Lübbig A. Die Psychiatrie in den Exilromanen von Ernst Weiß. Aachen: Shaker; 1998.

36. Weiß E. Der Augenzeuge. Frankfurt a. M.: Suhrkamp; 1982.

37. Pazi M. Ernst Weiß: Schicksal und Werk eines jüdischen mitteleuropäischen Autors in der ersten Hälfte des 20. Jahrhunderts. Würzburger Hochschulschriften zur neueren deutschen Literaturgeschichte, Vol. 14. Frankfurt a. M.: Peter Lang; 1993.

38. Engel P. Nachwort. In: Weiß E. Der Augenzeuge. Frankfurt a. M.: Suhrkamp; 1982.

39. Theiss-Abendroth $P$. Was wissen wir wirklich über die militärpsychiatrische Behandlung des Gefreiten Adolf Hitler? [What Do we really know About How Lance-Corporal Adolf Hitler was Treated by German Military Psychiatry?]. Psychiat Prax. 2009; 36:35-9.

40. Armbruster J. Die Behandlung Adolf Hitlers im Lazarett Pasewalk 1918: Historische Mythenbildung durch einseitige bzw. spekulative Pathographie. [The treatment of Adolf Hitler at the Pasewalk Military Hospital in 1918. Historical Myth-Building Through Biased and Speculative Pathography]. J Neurol Neurochir Psychiatr. 2009;10(4):18-23.

41. Armbruster J. Edmund Forster (1878-1933). Lebensweg und Werk eines deutschen Neuropsychiaters. Husum: Matthiesen; 2005. (Abhandlungen zur Geschichte der Medizin und der Naturwissenschaften; vol. 102).

42. Armbruster J. Die Beziehung des Psychiaters Edmund Forster (18781933) zu Adolf Hitler (1889-1945). [The Relationship of the Psychiatrist Edmund Forster (1878-1933) to Adolf Hitler (1889-1945)]. In: Holdorff B, Kumbier E, editors. Schriftenreihe der Deutschen Gesellschaft für Geschichte der Nervenheilkunde; vol 15. Würzburg: Königshausen \& Neumann; 2009. p. 159-85.

43. Toland J. Adolf Hitler. Garden City, New York: Doubleday, 1976.

44. Weber T. Hitler's First War. Oxford, New York: Oxford University Press; 2010.

45. Eberle H. Hitlers Weltkriege: Wie der Gefreite zum Feldherrn wurde. Hamburg: Hoffmann und Campe; 2014.

46. Kershaw I. Hitler: 1889-1936: Hubris. New York, London: W.W. Norton \& Company; 2000. p. 101.

47. Hitler A. Mein Kampf. 855th ed. Zentralverlag der NSDAP., Frz. Eher Nachf. GmbH: München; 1943.

48. Trevor-Roper HR. The last days of Hitler. New ed. New York: Berkley publishing cooperation; 1947. p. 53. 